\title{
PENGARUH PEER EDUCATION TERHADAP PENGETAHUAN PERSONAL HYGIENE MASA MENSTRUASI REMAJA AWAL DI PONDOK PESANTREN PUTERI KOTA MAKASSAR
}

\author{
Ratnasari $^{1)}$, Fairus Prihatin Idris ${ }^{2),}$ Suharni A.Fachrin ${ }^{3)}$, Andi Asrina4), Een Kurnaesih ${ }^{\text {5), }}$ \\ $\operatorname{Arman}^{6}$. \\ ${ }^{1}$ Mahasiswa Pascasarjana Kesehatan Masyarakat, Universitas Muslim Indonesia, \\ email: ratnasari965@gmail.com \\ ${ }^{23344) 5)}$ Pascasarjana Kesehatan Masyarakat, Universitas Muslim Indonesia,
}

\begin{abstract}
WHO data in 2010, the highest incidence of reproductive tract infections (ISR) in the world is in the teens (35\%-42\%) and young adults (27\% -33\%). Indonesia has a hot and humid climate, so Indonesian women are more vulnerable to ISR. Health problem that often arise in adolescents is personal hygiene. The main factor is the lack of proper knowledge and information on hygiene management, especially during menstruation. The purpose of this study is to determine the effect of peer education and video media on knowledge personal hygiene menstrual actions in early adolescent female students. The method of the study used was a quasi-experimental design using the Two Group Pretest-Posttest Design. The variables of this study are knowledge, attitudes, and actions. The populations in this study are 174 people and a sample of 63 people in the peer education group and 63 in the video group with non-probability sampling techniques.

The results show that an increase in average knowledge before and after peer education and video media. There are differences in knowledge $(p=0,000)$ of young women about personal hygiene during menstruation in the intervention group before and after peer education. There are differences in knowledge $(p=0,000)$ of young women about personal hygiene during menstruation in the control group before and after giving videos.

The conclusion of this study is the influence of peer education and video media on knowledge personal hygiene actions during menstruation. It is necessary to intervene in the improvement of personal hygiene behavior in female students at the Islamic Boarding School.
\end{abstract}

Key Words : Peer Education, Video, Personal Hygiene, Female Students. 


\section{PENDAhuluan}

Pondok pesantren disebutkan sebagai tempat remaja/santri berkumpul, hidup bersama, saling membutuhkan, dan memiliki tujuan mempelajari ilmu agama. Lingkungan pesantren memiliki masalah kesehatan, khususnya remaja/santri kesadaran dalam kebersihan diri yang berakibat muncul berbagai penyakit salah satunya kesehatan reproduksi wanita. Hal tersebut dikarenakan kurangnya pengetahuan dan informasi yang tepat dalam pengelolaan kebersihan, khususnya pada remaja/santriwati yang sedang menstruasi (Zulva, rizka indana, 2011).

Berdasarkan data World Health Organization (WHO) tahun 2010, usia remaja (35\%-42\%) memiliki angka kejadian infeksi saluran reproduksi (ISR) tertinggi di dunia, dan dewasa muda $(27 \%$ $33 \%$ ) angka prevalensi candidiasis (25$50 \%)$, bacterialvaginosis (20-40\%) dan trichomoniasis (5- 15\%). Indonesia terdapat 43,3 juta jiwa remaja putri berusia 10-14 tahun berperilaku hygiene sangat buruk berdasarkan data statistik di Indonesia tahun 2012. Indonesia memiliki iklim yang panas dan lembab, sehingga wanita Indonesia lebih rentan mengalami ISR (Priyoto., 2014)

Tahun 2010, berdasarkan data yang dihimpun dari Badan Pusat Statistik dan Badan Perencanaan Pembangunan Nasional, remaja di Indonesia 63 juta berisiko melakukan perilaku yang tidak sehat. Angka insiden penyakit infeksi yang terjadi pada saluran reproduksi pada remaja (10-18 tahun), yaitu 35 sampai 42 persen serta dewasa muda (18-22 tahun) sebesar 27 hingga 33 persen. Misal, kurangnya tindakan merawat kebersihan organ reproduksi ketika menstruasi. Rahmatika (2010) dalam penelitiannya mengungkapkan bahwa faktor pemicu kasus ISR antara lain perilaku kurang dalam merawat hygiene ketika menstruasi sejumlah 30 persen, imunitas yang rendah sejumlah 10 persen, lingkungan buruk dan tata cara dalam penggunaan pembalut yang kurang tepat ketika menstruasi sejumlah 50 persen (Katarina, 2015).

Remaja putri Indonesia sebanyak $46 \%$ dari data nasional menunjukkan rendahnya perilaku hygiene diketahui hanya mengganti pembalut 2 kali per hari dan hanya $52 \%$ remaja yang mencuci tangannya sebelum memasang pembalut (Katarina, 2015). Pengetahuan hygiene menstruasi remaja putri di Indonesia ratarata rendah karena pertanyaan mengenai hygiene menstruasi rata-rata hanya dapat menjawab benar 9 dari 15 pertanyaan. Kurangnya akses informasi mengenai hygiene menstruasi tersebut menyebabkan rendahnya pengetahuan dan perilaku hygiene menstruasi. Remaja putri di Indonesia yang mendapatkan informasi hygiene menstruasi dari ibu mereka $57,6 \%$, $22,9 \%$ dari tenaga kesehatan, dan dari teman sebaya sebanyak $55,5 \%$ yang merupakan tertinggi kedua setelah ibu UNICEF, 2015 (Wash United, 2016)

Kesehatan khususnya masalah hygiene merupakan pilar yang berpengaruh terhadap kualitas hidup sumber daya manusia yang dapat menyebabkan infertilitas pada wanita (Ali, Tazeen Saeed, 2017). Dalam islam pun mengangkat isu mengenai masalah kesehatan dan kebersihan. Dalam Hadits (sumber hukum kedua setelah Alquran) dengan jelas juga dikatakan bahwa kebersihan merupakan sebagian dari iman, mukmin yang kuat lebih baik dan lebih disukai Allah swt. daripada mukmin yang lemah dan juga menganjurkan untuk menjaga kebersihan dengan segala usaha yang dapat dilakukan. Kurangnya pengetahuan kebersihan saat menstruasi akan meningkatkan resiko terganggunya keseimbangan kelembaban di daerah vagina jika tidak diperhatikan dengan baik maka akan mucul beragam keluhan yang dapat menyebabkan iritasi vagina (Zulva, rizka indana, 2011).

Hasil observasi di Pondok Pesantren Makassar menunjukkan bahwa distribusi penyakit di pondok pesantren dari tahun ke tahun berbeda khususnya 
dalam kesehatan reproduksi. Berdasarkan hasil wawancara menggunakan berbagai pertanyaan tentang personal hygiene menstruasi terhadap 16 siswi terdapat 11 siswi yang kurang memahami cara personal hygiene pada saat menstruasi 3 siswi mengatakan mengerti tentang kesehatan reproduksi wanita sedangkan 2 siswi mengatakan belum mengetahui tentang kesehatan reproduksi wanita terutama dalam hal personal hygiene pada saat menstruasi.

Berdasarkan hasil wawancara terhadap guru di pesantren didapatkan bahwa kegiatan pendidikan kesehatan tentang personal hygiene sudah pernah dilakukan di pesantren tetapi belum ada kegiatan siswa yang melanjutkan informasi tersebut ke teman. Oleh karena itu, kegiatan tersebut dianggap kurang efektif, sehingga peneliti tertarik meneliti tentang efektivitas peer education terhadap pengetahuan dan sikap personal hyigene masa menstruasi pada remaja awal di pondok pesantren puteri ummul mukminin kota Makassar.

Tujuan penelitian ini adalah untuk mengetahui pengaruh peer education dan media video terhadap pengetahuan personal hygiene menstruasi pada santriwati remaja awal. Kegiatan peer education dan media video merupakan metode kegiatan pembelajaran yang dapat menambah pengetahuan dan pengalaman khususnya tentang kesehatan reproduksi remaja. Mengetahui pengaruh intervensi manajemen hygiene menstruasi kesehatan reproduksi remaja menjadi modal untuk melakukan hal yang lain dalam upaya meningkatkan kualitas hidup remaja

\section{METODE}

Dalam penelitian ini metode yang digunakan adalah quasi eksperimental design dengan menggunakan rancangan Two Group Pretest-Posttest Design. Penelitian ini diawali dengan pemberian kuesioner (pretest), kemudian setelah itu peneliti memberikan intervensi edukasi dengan peer education. Untuk mengetahui pengaruh intervensi edukasi, peneliti melakukan pemberian kuesioner yang sama (posttest). Kuesioner yang digunakan adalah mengenai personal hygiene menstruasi kesehatan reproduksi remaja. Sedangkan pada grup kontrol dilakukan pretest kemudian diberikan video edukasi kemudian setelah peneliti memberikan video edukasi dilakukan posttest (Hidayat, A.Azis Alimul, 2009). Populasi dalam penelitian ini adalah seluruh santri kelas VII tingkat sekolah menengah (SMP) Pesantren Putri Ummul Mukminin Makassar yang berjumlah 173 santri dengan sampel adalah 63 orang kelompok intervensi (peer education) dan 63 orang kelompok kontrol (media video). Dengan kriteria inklusi pada penelitian ini meliputi, responden yang sudah menstruasi, siswa kelas VII Pesantren Puteri

Pengolahan data dilakukan secara manual yaitu dengan mengisi lembar observasi yang disediakan yang dimulai dengan observasi pemilihan responden kemudian melakukan pre test dan post test. Pengolahan data tersebut kemudian diolah menggunakan program SPSS statistic 21 dengan tahap Editing, Koding, Tabulasi data dan Analisa data. Setelah diberikan kode data selanjutnya dilakukan uji normalitas. Uji hipotesis yang digunakan dalam penelitian adalah uji Wilcoxon.

\section{HASIL DANPEMBAHASAN}

Hasil

1. Karakterisik Responden

Tabel 1 Distribusi Karakteristik Responden

\begin{tabular}{ccccc}
\hline $\begin{array}{c}\text { Karakteristik } \\
\text { Responden }\end{array}$ & $\begin{array}{c}\text { Kelompok } \\
\text { Peer } \\
\text { Education }\end{array}$ & $\begin{array}{c}\text { Kelompok } \\
\text { Video }\end{array}$ \\
\cline { 2 - 5 } & $\mathbf{n}$ & $\mathbf{\%}$ & $\mathbf{n}$ & $\mathbf{\%}$ \\
\hline $\begin{array}{c}\text { Sumber } \\
\text { Informasi }\end{array}$ & & & & \\
\hline Orang tua & 42 & $66,7 \%$ & 50 & 79,4 \\
\hline Media & 3 & $4,8 \%$ & 9 & 14,3 \\
\hline Tenaga Kesehatan & 18 & $28,6 \%$ & 2 & 3,2 \\
\hline Teman & 0 & 0 & 2 & 3,2 \\
\hline Jumlah & $\mathbf{6 3}$ & $\mathbf{1 0 0 \%}$ & $\mathbf{6 3}$ & $\mathbf{1 0 \%}$ \\
\hline & & & &
\end{tabular}


Besar sampel pada penelitian ini sebanyak 126 orang siswa yang terdiri dari 2 kelompok yaitu 63 orang siswa yang diberi intervensi yaitu peer education dan 63 orang siswa sebagai kelompok kontrol yang diberikan metode video

Berdasarkan tabel 1 tersebut, menunjukkan bahwa distribusi frekuensi responden berdasarkan sumber informasi yang didapatkan adalah sebagian besar responden mendapat informasi dari orangtua sebanyak 42 orang $(66,7 \%)$ pada kelompok intervensi dan 50 orang $(79,4 \%)$ pada kelompok kontrol. Responden mendapatkan informasi dari media sebanyak 3orang $(4,8 \%)$ pada kelompok intervensi dan 2 orang $(3,2 \%)$ pada kelompok kontrol. Sedangkan responden mendapatkan informasi dari tenaga kesehatan sebanyak 18 orang $(28,6 \%)$ pada kelompok intervensi dan 2 orang $(3,2 \%)$ pada kelompok kontrol. Dan sumber informasi dari teman sebanyak 2orang $(3,2 \%)$ pada kelompok kontrol.

2. Analisis Univariat

Tabel 2 Distribusi Frekuensi Pengetahuan Remaja Awal tentang Personal Hygiene Masa Menstruasi Kelompok Intervensi (Peer Education) Sebelum dan Sesudah Intervensi

\begin{tabular}{cccccc}
\hline No & Pengetahuan & Pre & \multicolumn{3}{c}{ Post } \\
\hline & & n & \% & n & \% \\
\hline $\mathbf{1 .}$ & Baik & 14 & 22,2 & 56 & 88,9 \\
\hline $\mathbf{2 .}$ & Cukup & 47 & 74,6 & 7 & 11,1 \\
\hline $\mathbf{3 .}$ & Kurang & 2 & 3,2 & 0 & 0 \\
\hline & Total & $\mathbf{6 3}$ & $\mathbf{1 0 0}$ & $\mathbf{6 3}$ & $\mathbf{1 0 0}$ \\
\hline & Berdasarkan & & tabel & tersebt
\end{tabular}

Berdasarkan tabel tersebut menunjukkan pengetahuan remaja awal sebelum dilakukan peer education bahwa sebanyak 14 orang $(22,2 \%)$ yang berpengetahuan baik pada kelompok intervensi, sedangkan yang berpengetahuan cukup sebanyak 47 orang $(74,6 \%)$ pada kelompok intervensi (peer education) dan Berpengatahuan kurang sebanyak 2 orang $(3,2 \%)$ pada kelompok intervensi (peer education)

Setelah dilakukan intervensi diperoleh peningkatan pengetahuan baik pada kelompok perlakuan yaitu sebanyak
56 orang $(88,9 \%)$, Sedangkan yang berpengetahuan cukup sebanyak 7 orang $(11,1 \%)$ pada kelompok intervensi (peer education)

Tabel 3 Distribusi Frekuensi Pengetahuan Remaja Awal tentang Personal Hygiene Masa Menstruasi Kelompok Kontrol (Video) Sebelum dan Sesudah Intervensi

\begin{tabular}{cccccc}
\hline \multirow{2}{*}{ No } & Pengetahuan & \multicolumn{2}{c}{ Pre } & \multicolumn{2}{c}{ Post } \\
\cline { 3 - 6 } & & n & $\mathbf{\%}$ & n & \% \\
\hline 1. & Baik & 16 & 25,4 & 46 & 73,0 \\
\hline 2. & Cukup & 44 & 69,8 & 17 & 27,0 \\
\hline 3. & Kurang & 3 & 4,8 & 0 & 0 \\
\hline & Total & $\mathbf{6 3}$ & $\mathbf{1 0 0}$ & $\mathbf{6 3}$ & $\mathbf{1 0 0}$ \\
\hline & & & & &
\end{tabular}

Berdasarkan tabel tersebut menunjukkan pengetahuan remaja awal sebelum dilakukan media video berpengetahuan baik pada kelompok kelompok kontrol sebanyak 16 orang $(25,4 \%)$, sedangkan yang berpengetahuan cukup sebanyak 44 orang $(69,8 \%)$. Dan Berpengatahuan kurang kelompok kontrol sebanyak 3 orang $(4,8 \%)$.

Setelah dilakukan intervensi diperoleh peningkatan pengetahuan baik pada kelompok kontrol sebanyak 46 orang $(73,0 \%)$ yang berpengetahuan baik. Sedangkan yang berpengetahuan cukup kelompok kontrol sebanyak $(27,0 \%) 17$ orang.

3. Analisis Bivariat

Pengetahuan remaja awal pada kelompok intervensi dan kontrol untuk melihat perubahan tersebut dilakukan dengan uji Wilcoxon. Wilcoxon merupakan uji non-parametrik (data berdistribusi tidak normal) dan merupakan uji untuk data berpasangan dengan model pengukuran sebelum dan sesudah (one group before and after design).

Tabel 4 Hasil Uji Wilcoxon Pengetahuan Remaja Awal pada Kelompok Perlakuan dan Kontrol

\begin{tabular}{cccc}
\hline Variabel & $\begin{array}{c}\text { Mean } \\
\text { pre }\end{array}$ & $\begin{array}{c}\text { Mean } \\
\text { Post }\end{array}$ & P \\
\hline $\begin{array}{c}\text { Kelompok } \\
\text { Peer }\end{array}$ & 65,2 & 85,4 & 0,000 \\
\hline
\end{tabular}




\begin{tabular}{cccc}
\hline Education & & & \\
\hline $\begin{array}{c}\text { Kelompok } \\
\text { Vidio }\end{array}$ & 65,6 & 79,2 & 0,000 \\
\hline & Berdasarkan & tabel & tersebut,
\end{tabular}

diketahui bahwa terdapat perbedaan nilai rata-rata pengetahuan remaja awal sebelum dan sesudah kelompok intervensi (peer education) yaitu dari 65,2 menjadi 85,4 . Hasil uji wilcoxon diperoleh nilai $p=0,000, \quad$ artinya secara statistik menunjukkan terdapat hubungan pengetahuan dengan peer education, sedangkan pada kelompok kontrol rata-rata yaitu dari 65,6 menjadi 79,2. hasil uji wilcoxon diperoleh nilai $p=0,000$, artinya secara statistik menunjukkan terdapat hubungan pengetahuan dengan metode video.

\section{Pembahasan}

Pengetahuan merupakan hasil penginderaan yang akan mengubah pemahaman menjadi lebih baik melalui indera mata, hidung telinga yang didukung oleh media dan metode yang tepat. Intensitas perhatian dan presepsi terhadap objek sangat mempengaruhi penginderaan sampai menghasilkan pengetahuan (Notoatmodjo, 2012).

Peer education (pendidik sebaya) adalah dikenal sebagai dasar dari remaja, untuk remaja dan oleh remaja. Umumnya prinsif yang bekerja lebih terbuka dan bebas mengungkapkan permasalahannya dengan teman-teman seusianya. Peer educator juga dikenal sebagai sekelompok siswa yang memberikan bantuan kepada siswa yang mengalami kesulitan dalam memahami bahan pelajaran yang dipelajari dengan syarat siswa tersebut telah tuntas terhadap bahan pelajaran.

Peer education pada penelitian ini melibatkan siswi kelas VIII SMP yang merupakan teman sebaya pelajar dalam satu angkatan. Hal ini sesuai dengan menurut Lutfiani (2011) yang menyatakan bahwa peer education merupakan informasi dan edukasi yang dilakukan oleh dan untuk kalangan yang sebaya dalam proses komunikasi yaitu kelompok pelajar, mahasiswa, profesi, dan sesama rekan kerja (Lutfiana, 2011).

Pada penelitian ini responden dibagi dalam kelompok kecil memiliki kepentingan yang sama yaitu untuk mempelajari materi tentang personal hygiene masa menstruasi yang beranggotakan 5-6 siswi. Hal tersebut sesuai dengan menurut (Fitriani, 2011) bahwa salah satu strategi yang digunakan dalam metode peer education yaitu strategi pendidikan yang membahas suatu topik dengan cara bertukar pikiran dalam kelompok kecil untuk mencapai tujuan tertentu secara bersama. Jumlah anggota kelompok kecil maksimal 15 orang (Notoatmodjo, 2012).

Pemilihan peer educator sebelum memberikan pendidikan kesehatan untuk kelompoknya, berdasarkan nilai pretest tertinggi dan tes lisan untuk mengetahui pemahaman tentang materi personal hygiene masa menstruasi. Peer educator telah diberikan pengarahan terlebih dahulu tentang teknis penyampaian materi. Karakteristik peer educator menurut Nugroho (2016) memiliki pengetahuan tentang kesehatan reproduksi, sifat kepemimpinan, kemampuan komunikasi dan hubungan yang baik dengan teman, serta direkomendasikan oleh guru di sekolah (Nugroho, Dedi Tri, 2016).

Hasil analisis bivariat diperoleh bahwa terdapat perbedaan nilai rata-rata pengetahuan siswi sebelum dan sesudah peer education yaitu dari 65,2 menjadi 85,4 pada kelompok intervensi. Hasil uji wilcoxon diperoleh nilai $p=0,000$, artinya secara statistik menunjukkan terdapat hubungan pengetahuan dengan dilakukan peer education.

Dalam proses penelitian didapatkan bahwa remaja putri di Pesantren Ummul Mukminin menyukai metode peer edukasi dalam peningkatan pengetahuan mengenai personal hygine masa menstruasi pada remaja awal. Hal ini disebabkan karena remaja putri merasa lebih terbuka dan bebas menyampaikan 
hal-hal yang dianggap sensitif atau malu diceritakan kepada orang lain. Remaja putri juga menyampaikan dengan bercerita dengan teman seusia apalagi teman sekelas yang selalu bersama dengan dirinya lebih menyenangkan dan merasa apa yang disampaikannya juga pernah dialami oleh teman sebayanya.

Hal tersebut sejalan dengan penelitian Syarifatul Fikriyah tentang pengaruh metode peer education terhada pengetahuan kesehatan reproduksi pada SMP di Pondok Ta'Mirul Islam Surakarta tahun 2017 (Fikriyyah, Syarifatuul, dkk, 2017). Hasil uji statistik menggambarkan adanya pengaruh metode peer education terhadap pengetahuan keputihan siswi kelas II SMP pada pendidikan kesehatan. Dengan uji wilxocon ditunjukkan dengan nilai $\mathrm{p}=0,000$.

Pengetahuan remaja awal sebelum dilakukan peer education bahwa sebanyak 14 orang (22.2\%) yang berpengetahuan baik, yang berpengetahuan cukup sebanyak 47 orang (74.6\%), dan berpengetahuan kurang sebanyak 2 orang (3.2\%) pada kelompok intervensi (peer education). Pada kelompok intervensi sebelum dilakukan intervensi masalah yang ditemukan adalah pembersih yang digunakan saat membersihkan alat kelamin rata-rata remaja putri menjawab dalam membersihkan alat kelamin harus menggunakan sabun sedangkan dalam teori dijelaskan bahwa dalam membersihkan vagina menggunakan alat pembersih kimiawi tertentu akan merusak keasaman vagina.

Membersihkan vagina tidak diperbolehkan menggunakan cairan pembersih (douches), deodoran atau spray, sabun yang keras, serta tisu berwarna atau berparfum. Bahan-bahan tersebut memiliki rangsangan yang dapat menimbulkan peradangan pada bibir kemaluan dan liang senggama dengan adanya keluhan gatal dan keptihan. Cairan pembasuh vagina yang bersifat basa dapat merusak keasaman normal vagina dan memicu pertumbuhan kuman di daerah vagina secara abnormal seperti adanya keputihan (El Manan, 2011).

Setelah dilakukan intervensi diperoleh peningkatan pengetahuan baik pada kelompok peer education yaitu sebanyak 56 orang $(88,9 \%)$, sedangkan yang berpengetahuan cukup sebanyak 7 orang $(11.1 \%)$ pada kelompok intervensi (peer education). Setelah intervensi kelompok peer education berdasarkan indikator pengetahuan remaja putri sangat setuju tentang tujuan menjaga kebersihan organ kewanitaan saat menstruasi dan hal yang harusnya dilakukan pertama kali sebelum membasuh alat kelamin sebesar $100 \%$. Hal ini karena sebelum melukan peer education membagi dalam kelompokkelompok kecil para remaja telah mengetahui tujuan bersama yaitu untuk mengetahui cara menajaga kebersihan diri saat haid dan tujuan menjaga kebersihan organ reproduksi sehingga remaja sangat berperang aktif dalam proses peer education.

Terkait peningkatan yang lebih tinggi yaitu dengan selisih $43,8 \%$ sebelum dan sesudah pemberian peer education tentang pembersih yang digunakan saat membersihkan alat kelamin. Hal ini dikarenakan remaja memiliki anggapan bahwa pembersihan yang digunakan pada saat membersihkan alat kelamin adalah menggunakan sabun untuk pewangi namun nyatanya vagina adalah area yang sangat sensitif sehingga menggunakan bahan tertentu bisa menyebabkan iritasi, infeksi, serta keseimbangan $\mathrm{pH}$ vagina akan terganggu.

Remaja lebih senang, nyaman, dan terbuka apabila mendiskusikan permasalahan yang berhubungan dengan kesehatan reproduksi dengan teman sebaya dibandingkan dengan orang tua. Hal tersebut dikarenakan mereka sudah saling bertemu, terbuka, dan merasa bebas. Teman sebaya juga lebih dapat menerima perbedaan pendapat dan lebih memenuhi 
kebutuhan remaja daripada orang dewasa (Imron, 2012).

Peneliti menganggap Peer Education lebih efektif dilakukan karena metode ini lebih menekankan untuk membangun hubungan interpersonal antara peer educator dengan peserta peer education. Teman sebaya lebih mudah mengemukakan pikiran, perasaannya, dan merasa lebih terbuka sehingga pesan yang sensitif dapat disampaikan dengan santai. Kondisi tersebut memudahkan proses transfer informasi dan meningkatkan pengetahuan peserta peer education, sehingga pengetahuan remaja terutama masalah seksualitas dan kesehatan reproduksi dapat lebih banyak diperoleh.

Selain dengan metode peer edukasi, pemberian video yang menjelaskan mengenai personal hygine pada masa menstruasi juga memiliki manfaat. Media video dinilai efektif bersifat komunikatif serta memiliki daya tarik tersendiri. Video dapat memberikan kesan yang sebenarnya atas fakta-fakta di lapangan. Saat ini, video juga merupakan salah satu media pembelajaran yang banyak digunakan guru (Fikriyyah, Syarifatuul, dkk, 2017). Durasi pemberian video dalam penelitian ini adalah 6 menit yang menayangkan mengenai prosedur kebersihan masa menstruasi, dalam penyajian video dengan tampilan gambar nyata akan memotivasi peserta didik untuk percaya diri.

Dalam teori belajar dikenal teori belajar kognitif (Social cognitive theory) sosial yang diusung oleh Albert Bandura, menyatakan bahwa peran penting dalam pembelajaran adalah faktor sosial dan kognitif. Albert Bandura dikenal sebagai salah satu arsitek utama teori kognitif sosial. Albert Bandura mengembangkan model determinisme resiprocal yang terdiri dari tiga faktor utama: perilaku, person/kognitif, dan lingkungan. Dikatakan bahwa ketika murid belajar, mereka dapat mempresentasikan atau mentransformasi pengalaman mereka secara kognitif. Dalam pengkondisian operan, hubungan terjadi antara pengalaman lingkungan dan perilaku (Irham, 2013).

Bandura sangat familiar dengan eksperimen bobo doll. Hal tersebut disebabkan karena eksperimen bobo doll menggunakan seorang anak kecil bersama sebuah boneka. Dalam prosesnya di sebuah ruangan yang terpisah dengan sketsa kaca yang tembus pandang (one way screen) anak kecil diletakkan, di sebelah ruangannya seorang dewasa dan boneka telah ditempatkan sehingga si anak dapat melihat semua aktivitas orang dewasa tersebut dalam melakukan tindakan-tindakan dengan bonekanya secara bervariasi, memainkannya, memperlakukannya dengan kasar, (dipikul, ditendang, dan sebagainya) sesuai dengan skenario yang telah dibuat dalam jangka waktu tertentu (Irham, 2013).

Beberapa saat kemudian, setelah diberi waktu jeda giliran si anak ditempatkan pada ruangan yang sama persis dengan ruangan yang ditempati oleh orang dewasa dengan bonekanya. Beberapa saat diamati, awalnya anak tersebut tidak memunculkan perilaku aneh dan hanya bermain dengan wajar bersama bonekanya. Setelah beberapa saat bermain dengan bonekanya, mulai tampak dan muncul perilaku kasar serta agresif yang dilakukan seperti orang dewasa dalam meperlakukan bonekanya. Perilaku yang diperlihatkan tersebut sama persis yang dilakukan orang dewasa terhadap boneknaya. Proses dalam penirauan inilah yang dikenal sebagai proses modeling oleh Bandura (Irham, 2013).

Hasil eksperimen tersebutlah dikenal dengan teori belajar sosial (social learning). Teori belajar sosial dari Albert Bandura menunjukkan pentingnya proses mengamati dan meniru perilaku dalam proses belajar, mempengaruhi reaksi orang lain dalam proses belajar, serta membentuk sikap siswa. Diartikan sebagai proses belajar pada individu akan lebih banyak 
terjadi melalui proses pengamatan terhadap situasi dan kondisi lingkungannya. Oleh sebab itu, teori ini dengan tegas menjelaskan bahwa kebanyakan perilaku manusia dipelajari sebagai hasil pengamatan melalui proses modelling. Dari pengamatan satu ke bentuk pengaman lainnya yang membentuk sebuah perilaku baru yang akan digunakan sebagai pedoman dan patokan dalam bertindak (Irham, 2013).

Adapun hasil analisis bivariat pada kelompok kontrol dengan pemberian video nilai rata-rata yaitu dari 65,6 menjadi 79,2 dengan nilai $p=0,000 \quad(<0,05)$ artinya terdapat perubahan pengetahuan dengan dilakukan media vidio. Hal tersebut sesuai dengan hasil penelitian Hendri Winata bahwa media pembelajaran mempunyai pengaruh signifikan terhadap motivasi belajar siswa tahun 2016 (Hendri, Winata, 2016). Media memberikan peranan penting dalam proses pembelajaran, apabila media tidak digunakan dalam proses pembelajaran maka dapat menjadikan peserta didik kurang termotivasi untuk belajar. Media pembelajaran yang dapat digunakan dalam edukasi tentang personal hygiene masa menstruasi salah satunya adalah media video.

Kelompok pemberian video yang berpengetahuan baik sebanyak 16 orang $(25,4 \%)$, pengetahuan cukup sebanyak 44 orang $(69,8 \%)$, dan berpengetahuan kurang sebanyak 3 orang $(4,8 \%)$ sebelum diberikan media video. Berdasarkan hasil penelitian di lapangan didapatkan bahwa siswi tidak begitu tahu frekuensi dalam mengganti pembalut karena rata-rata siswi mengatakan bahwa pembalut diganti hanya dua kali dalam sehari. Sedangkan dalam teori diketahui bahwa penggunaan pembalut selama menstruasi idealnya harus diganti secara teratur 3 sampai 5 kali sehari atau setiap 4 jam sekali, pada saat banyak (El Manan, 2011).

Siswi juga kurang memahami dampak yang akan terjadi jika tidak sering mengganti pembalut yang akan mengakibatkan bakteri mudah berkembangbiak ke dalam vagina dan menyebabkan infeksi. Pada saat menstruasi pembalut harus diganti secara teratur 3-5 kali atau setiap setelah mandi dan buang air besar ataupun kecil. Penggantian pembalut yang tepat apabila di permukaan pembalut telah ada gumpalan darah. Dikarenakan gumpalan darah yang terdapat di permukaan pembalut merupakan tempat berkembangnya bakteri dan jamur.

Ada beberapa hal yang perlu diperhatikan terkait praktik kebersihan saat menstruasi, diantaranya menjaga kebersihan dengan mandi 2 kali menggunakan pembalut yang aman yaitu yang tidak mengandung gel karena gel dapat menyebabkan iritasi, mengganti pembalut 4 jam sekali, membeli pembalut dalam keadaan tertutup, menggunakan air mengalir untuk membersihkan area kewanitaan, membersihkan vagina mulai dari depan lalu ke belakang, menggunakan air dengan sabun yang lembut di daerah vagina, tidak menyemprotkan sabun ke vagina karena dapat mengganggu pertahanan setempat bahkan dapat menyebabkan iritasi dan alergi. Sebelum membung pembalut terlebih dahulu dicuci sampai bersih dan membungkusnya dengan kertas/plastik dan membuangnya di tempat sampah (El Manan, 2011).

Kelompok kontrol setelah pemberian video remaja sangat setuju mengenai pengertian personal hygiene, tujuan menjaga kebersihan organ kewanitaan, dan bahan pembalut yang digunakan saat menstruasi. Hal ini karena dalam proses pemutaran video tentang kebersihan menstruasi yang berdurasi 6 menit hal yang pertama kali didengarkan adalah mengenai pengertian dan tujuan menjaga kebersihan organ reproduksi.

Terkait peningkatan yang lebih tinggi sebelum dan sesudah pemberian vidio dengan selisi 50,8\% adalah tentang pembersih yang digunakan saat membersihkan alat kelamin. Hal ini 
sebelum dilakukan intervensi rata-rata remaja menjawab dalam pembersih yang digunakan saat membersihkan alat kelamin adalah menggunakan sabun. Pengetahuan remaja putri tentang pemakaian sabun pembersih kewanitaan dalam jangka waktu panjang akan timbul pengikisan bakteri baik dan mengakibatkan infeksi genetalia interna maupun esterna dari keputihan patologis sampai kanker serviks (Suryandari, 2013). Membasuh daerah kewanitaan dengan air bersih merupakan cara terbaik membersihkan daerah kewanitaan.

Video merupakan teknologi yang digunakan untuk merekam, menangkap, memproses, mentransmisikan, dan menata ulang gambar bergerak. Kegunaan media video memungkinkan pemutaran ulang, gambar yang ada di layar monitor membantu pembelajar dalam pemahaman dan pengecekan. Teknik yang digunakan adalah Picture and Sound (sebagian gambar dan suara). Dalam teknik ini mendorong para peserta didik bertukar informasi karena terjadi "information gap" antar mereka (Zahrotaul, 2012).

Peneliti berkesimpulan bahwa dalam proses pembelajaran video merupakan media yang dapat digunakan karena mampu memberikan respon yang lebih efektif terhadap peserta didik. Media video memberikan tayangan bergerak dan animasi yang dapat menarik perhatian peserta didik lebih lama. Penggunaan media edukasi yaitu video tentang personal hygiene lebih meningkatkan pemahaman peserta didik.

Hal tersebut sesuai dengan yang peneliti dapatkan dalam proses penelitian bahwa peningkatan pengetahuan tentang personal hygiene bisa menggunakan metode peer education dan metode video. Proses peer education dan media video dalam proses pembelajaran meningkatkan fokus remaja dalam memahami informasi yang diberikan.

Remaja sangat penting untuk meningkatkan pengetahuan tentang kesehatan reproduksi. Diantaranya, pengetahuan tentang perubahan yang terjadi secara fisik, kejiwaan, dan kematangan seksual agar remaja memiliki sikap dan perilaku yang bertanggung jawab dalam mengatasi berbagai keadaan yang membngungkan (Fatikah, 2010).

\section{KESIMPULAN}

Hasil uji wilcoxon diperoleh nilai $p=0,000, \quad$ artinya secara statistik menunjukkan terdapat hubungan pengetahuan dengan peer education, sedangkan pada kelompok kontrol hasil uji wilcoxon diperoleh nilai $p=0,000$, artinya secara statistik menunjukkan terdapat hubungan pengetahuan dengan metode video.

\section{REFERENSI}

Ali, Tazeen Saeed, 2017. Are Unhygienic practice during the menstrual, partum, and post partum periods risk factor for secondary infertility. J Health Popul Nutr 25.

El Manan, 2011. Miss V. Buku Biru, Jogjakarta.

Fatikah, 2010. Hubungan Pengetahuan Kesehatan Reproduksi Remaja Putri Terhadap Sikap Menghadapi Premenstrual Syndrome di SMAN 5 Surakarta (skripsi). Medan FKM Univ. Sumat. Utara.

Fikriyyah, Syarifatuul, dkk, 2017. Pengaruh metode peer education terhadap pengetahuan kesehatan reproduksi pada siswi smp d pondok Ta'Mirul Islam Surakarta. J. Nas. 1 No 2.

Fitriani, 2011. Promosi Kesehatan. Graha Ilmu, Yogyakarta.

Hendri, Winata, 2016. Manajemen Kearsipan ; untuk Organisasi Publik, Politik, dan Kemsyarakatan. Pustaka Setia, Bandung. 
Hidayat, A.Azis Alimul, 2009. Metode Penelitian Keperawatan dan Tekhnik Analisis Data. Salemba Medika., Jakarta.

Imron, 2012. Pendidikan Kesehatan Reproduksi Remaja: Peer Education dan Efektivitas Program KIR-KRR di Sekolah. Ar Ruzz Muhammad Irham dan Novan Ard, Yogyakarta.

Irham, 2013. Psikologi Pendidikan; Teori dan Aplikasi dalam Proses Pembelajaran. ArRuzz Media., Jogyakarta.

Katarina, 2015. Personal hygiene remaja putri ketika menstruasi. J. Nas.

Lutfiana, 2011. Pengaruh Peer Education Terhadap Pengetahuan Sikap. J. Nas.

Notoatmodjo, 2012. Ilmu perilaku kesehatan. rineka cipta, Jakarta.

Nugroho, Dedi Tri, 2016. Penerapan metode peer teaching untuk meningkatkan prestasi siswa kelas $X$ di SMK TamanSiswa Jetis Yogyakarta. Fak. Teh. Univ. Negeri Yogyak.

Priyoto., 2014. Teori Sikap dan Perilaku dalam Kesehatan. Nuha Medika., Yogyakarta.

Suryandari, 2013. Hubungan pemakaian pembersih vagina dengan kejadian keputihan pada remaja puti. J. Kebidanan 4.

Zulva, rizka indana, 2011. pengaruh peer education terhadap sikap manajemen higiene menstruasi pada santriwati remaja awal di pondok pesantren al-qodiri kabupaten jembe. 